\title{
Historic Cities and Tourism: Functional Dynamics and Urban Policy
}

\author{
Miguel Ángel Troitiño Vinuesa ${ }^{*}$ and Libertad Troitiño Torralba
}

Department of Human Geography, University Complutense of Madrid. Spain

\begin{abstract}
Within the context of far-reaching functional and social changes in the urban environment, historic Spanish cities are consolidating their position as important tourist destinations. Old and new functions coexist in permanent tension, the tension of change, and urban and tourism planning faces problems in adapting older cities scapes to new needs. An interesting process of urban recovery is taking place, with different impacts on different types of city, while the number of visitors, mostly Spanish, is rising significantly. At the same time, the stock of hotels and restaurants has been modernised, hospitality services improved, city centres made more compatible, and the range of cultural events widened. The explosion of mass tourism offers a new opportunity to address the issue of the functionality of the historic city and to establish new uses for underemployed heritage and city centre features.
\end{abstract}

Keywords: Historic city, tourist destinations, functional dynamics, urban policies.

\section{HISTORIC CITIES AND TOURISM: A QUESTION OF OPPORTUNITY AND RATIONALITY}

In Spain, the concept of the historic city as a tourist resource has evolved from older visions which merely valued architectural highlights and museums to the wider consideration of historic, cultural, morphological, economic, social, and symbolic dimensions. All in all, we are dealing with a historic-cultural product, which contributes to making a place special, so that given its own identifying features it can become a focal point for tourism. However, while providing opportunities for recovering architectural heritage and the functional revitalisation of historic city centres, tourism also generates negative effects in social, functional, environmental, and landscape terms [1].

Spain is a country which offers a great richness and diversity of cultural heritage, with 39 sites on the World Heritage List (2007) and 829 sites of cultural interest (SCI), together with a wide variety of landscapes and cultural and gastronomic features, yet it lacks an international image as a destination for cultural tourism. This is despite the fact that some cities, such as Granada, Cordoba, Seville, Toledo, and Santiago de Compostela became part of the itinerary of illustrious romantic travellers relatively early on, and were later incorporated into the tour circuit of southern European cities. Over the past two decades, the relevant changes within the context of the emergence of cultural tourism in Spain [2] have followed the theme of empowering and diversifying historic cities as destinations for internal tourism.

From the Urban Rehabilitation Pilot Study, set up during the early years of the democratic transition, to the URBAN Programmes supported by EU funding, there has been a qualitative leap in the value of the heritage dimension and in the models of urban intervention, with recovery and value enhancement gaining in importance. Tourism has played an

*Address correspondence to this author at the Department of Human Geography, University Complutense of Madrid, Spain; Tel: 91-450-3849; E-mail: matroiti@ghis.ucm.es important role in this process, although at different levels depending on the importance of the historic city as a tourist destination, by generating business optimism and allowing the economic dimension of our cultural heritage to be visualised.

Traditional approaches to urban planning, passive protection of heritage buildings and mere promotion of tourism are being superseded as the cultural, economic, environmental, and functional dimensions required by tourism are taken on board. Cities such as Avila, Alcala de Henares, Cuenca, Morella, Cordoba, Granada, Toledo, Gerona, Salamanca, Santiago de Compostela, Segovia, Caceres or Baeza are exploiting all available resources or developing new ones (public-private joint ventures, consortia, etc) to help prepare them as competitive tourist destinations with their own identity.

At the beginning of the century, Spain's share of the European cultural tourism market stood at $8.2 \%$, with a mere $10.6 \%$ of visitors coming to Spain for cultural reasons [3]. The Integrated Spanish Plan for Quality Tourism (20002006) then gave strategic priority to the development of cultural tourism, given that the cultural motive features more and more significantly in tourist visits. At the end of 2001, the Culture and Language Tourism Initiative was set up, with 40 specific measures designed by the central Spanish government as part of its tourism policy to encourage cultural tourism.

2006 was a good year for tourism in Spain, with 53.5 million international tourists and a $4 \%$ increase on 2005 [4]. The expansion of internal demand from the end of the 20th century onwards has been fundamental in explaining the tourist dynamics of historic cities. However, changes in patterns of demand, competition among destinations, and the sudden appearance of low cost airlines on the market, which allow more Spaniards to travel abroad, mean that for some historic cities the number of travellers and overnight stays has flattened out. 
In general, the introduction of tourist activities in historic cities has not been free of conflict, although this has not been felt so strongly in the more dynamic and multifunctional urban contexts. A good example is Santiago de Compostela, a pioneering city in integrated rehabilitation programs and the realisation of new models of management (Special Plan for the Historic City, Santiago Consortium, Plan for Tourism Excellence), which has solved the problems arising from the functional and physical recovery in a rather satisfactory manner, as well as the problems related to the powerful impact of tourism, especially during the Xacobeo years, with more than eight million visitors. Other cities, such as Avila, Salamanca, Gerona, Cuenca, Leon, or Alcala de Henares, are also dealing with their problems in a satisfactory way, and tourism has played an outstanding role in the processes of heritage recovery and functional revitalisation.

\section{BASIC FEATURES OF HISTORIC CITIES AS TOURIST DESTINATIONS}

Historic cities form an essential part of the culturally motivated urban tourism market. Historic centres stand out in the Spanish urban system for their extraordinary historic and cultural values. Some of these cities, Toledo, Seville, Granada (Fig. 1) or Cordoba are traditional tourist destinations, while others such as Avila, Salamanca, Cuenca, Caceres, Gerona or Morella have joined the list more recently. The "Tourism, Heritage and Development" research group at Madrid's Complutense University estimates that some of these destinations attract close to or over a million visitors a year [5].

Tourism has gone through a boom in many of these cities over the last fifteen years. From the middle of the 1990s up to 2005 , the number of visitors has grown at an average year- on-year rate of $6 \%$. Factors explaining this expansion are diverse in nature: an increase in cultural consumption, the search for the unusual, fragmentation of the holiday period, historic cities adopting tourism as an incentive for local development, and the strategies of some tourist operators or the arrival of low-cost airlines, essential for cities, such as Santiago, Tarragona or Gerona.

The number of tourists has grown in parallel to the increase and modernisation of accommodation capacity. Most of Spain's World Heritage Cities have doubled the number of hotel beds in the last fifteen years (Fig. 2).

The analysis of visitor trends shows tourism taking place within a leisure context, so that while the total number of visitors to cities is increasing, the number of visitors to important historic buildings or museums has steadied or is even falling (Table 1).

Tourist trends highlight the existence of three clearly differentiated stages: a high season, corresponding to the summer months; a middle season during spring and autumn; and a low season over the winter months. Although we are looking at destinations with less seasonal variation than are typical of other tourist categories, there are notable differences between weekends and working days, which tend to be more acute in cities where the number of domestic visitors travelling short distances at the weekends increases (Segovia, Avila, Toledo, etc). In general, there is a trend towards the gradual shortening of the low season.

Spanish visitors to historic cities are clearly predominant (70-80\%), with some exceptions such as Granada, Toledo or Seville. After the events of September 2001 in New York, the number of visitors from the US and Japan decreased though this was offset, at least until 2005, by the increase in

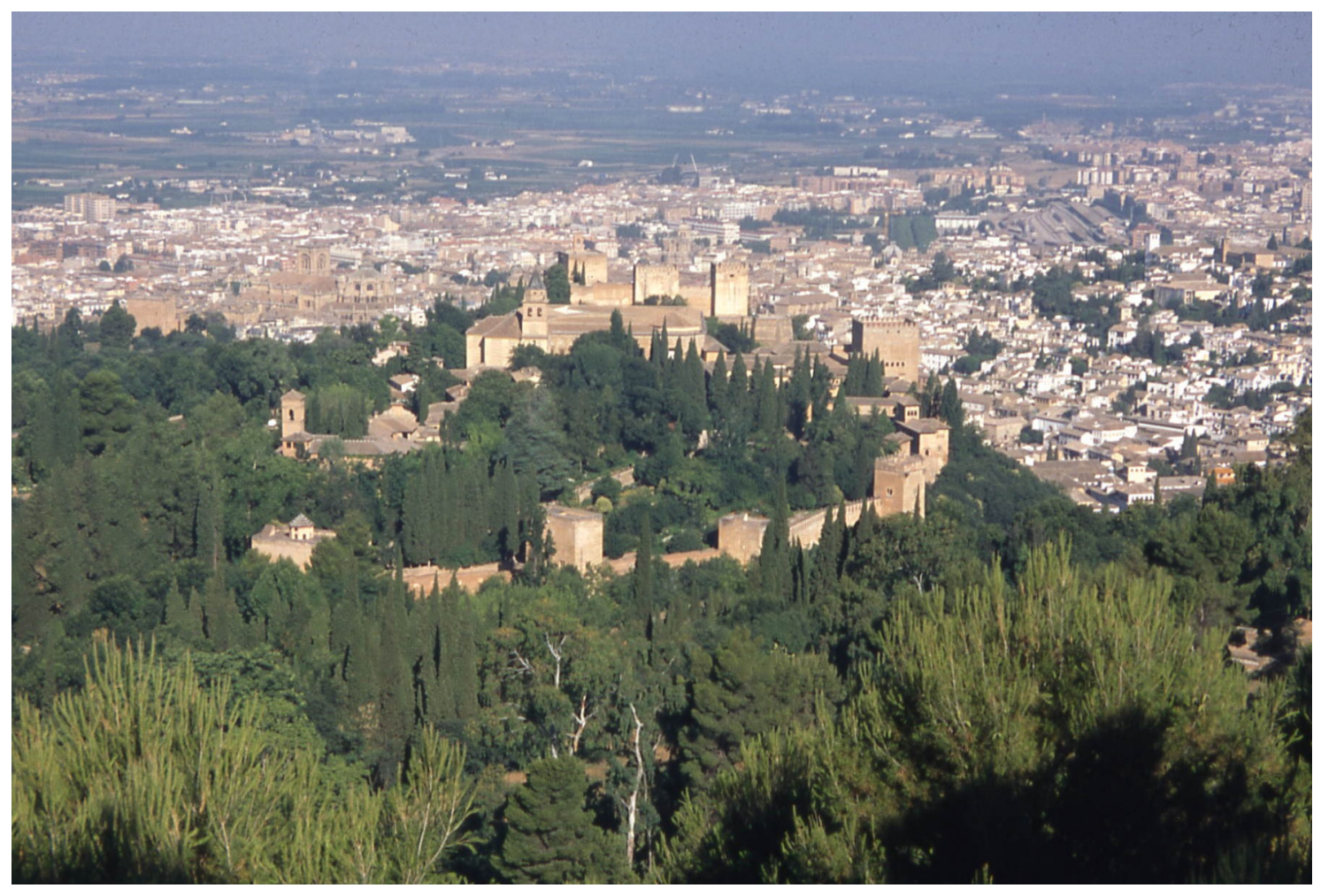

Fig. (1). Alhambra, Granada. 


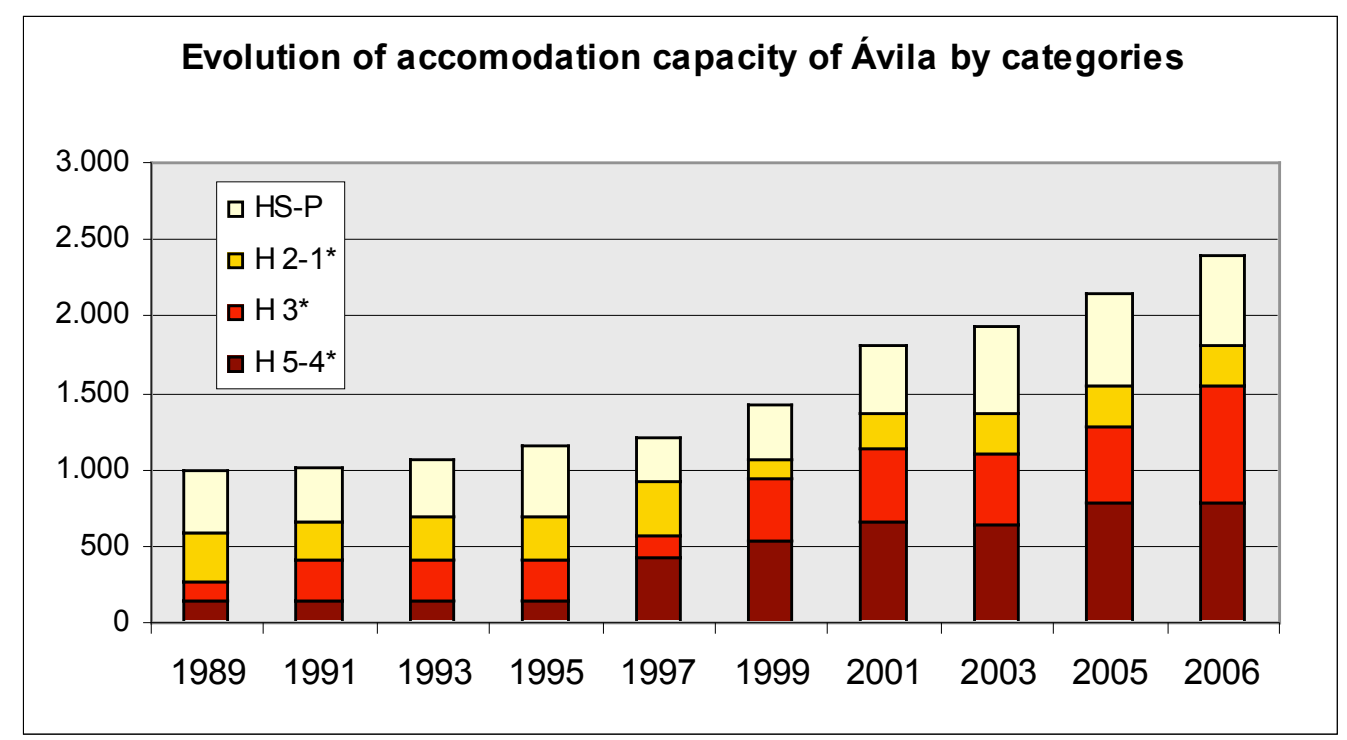

Fig. (2). Evolution of accommodation capacity of Avila by categories.

domestic visitors. The level of repeat visits, in the case of individual visitors, stands at $30-35 \%$ in many of the cities studied. This is particularly evident for example in the destinations inside the Madrid tourist region, such as Alcala de Henares, Toledo, Segovia or Avila [6].

Analysing the typology of the visitor to historic buildings in detail is a complex undertaking. As an example, we have analysed two specific cases, the city walls of Avila and St. Tomé Church in Toledo. In both cases, the studies show a clear dominance of individual visitors, making up $94.84 \%$ of visitors to the Avila walls and $70.84 \%$ to St. Tomé.
In the case of the Avila walls, the analysis of individual visitors shows a greater preference for visits in summer, with $34.61 \%$ coinciding with the overall holiday season. In spring and autumn, we find similar average figures, $28.46 \%$ and $22.83 \%$, respectively, and winter is the season with the lowest number of visits, especially in Avila where the winter climate acts as a deterrent (14.10\%). Visitor patterns to St. Tomé do not present large variations, spring being the season with the highest figures, at $34.97 \%$, while summer and autumn have very similar levels, $25.84 \%$ and $22.39 \%$, respectively.

Table 1. Number of Visitors to Major Monuments in Spain, 2003-2005

\begin{tabular}{|c|c|c|c|c|c|}
\hline & 2003 & 2004 & \%var. 03-04 & 2005 & \%var. 04-05 \\
\hline Seville Cathedral & 1.277 .032 & 1.264 .667 & $-0,97$ & 1.300 .883 & 2,86 \\
\hline Cordoba Mosque & 1.047 .383 & 1.040 .679 & $-0,64$ & 1.122 .338 & 7,85 \\
\hline The Alhambra, Granada & 2.029 .322 & 1.987 .686 & $-2,05$ & 2.012 .596 & 1,25 \\
\hline Avila City Wall & 177.350 & 233.591 & 31,71 & 182.073 & $-22,05$ \\
\hline Segovia Castle & 541.825 & 493.758 & $-8,87$ & 497.928 & 0,84 \\
\hline St Tomé Church, Toledo & 418.351 & 442.242 & 5,71 & 420.230 & $-4,98$ \\
\hline St Tomé Church, Toledo & 2.056 .448 & 2.260 .661 & 9,93 & 2.376 .205 & 5,11 \\
\hline Royal Palace, Madrid & 775.617 & 720.710 & $-7,08$ & 806.775 & 11,94 \\
\hline El Escorial Monastery & 539.278 & 504.238 & $-6,5$ & 504.609 & 0,07 \\
\hline Cordoba Synagogue & 347.300 & 256.000 & $-26,28$ & 402.000 & 57,03 \\
\hline Medina Azahara, Cordoba & 183.108 & 193.035 & 5,42 & 183.621 & $-4,88$ \\
\hline Royal Palace, Aranjuez & 304.616 & 298.779 & $-1,92$ & 322.103 & 7,81 \\
\hline Granada Cathedral & - & 428.481 & - & 448.225 & 4,61 \\
\hline Royal Chapel, Granada & - & 409.486 & - & 407.962 & $-0,37$ \\
\hline Casa de la Pedrera (Barcelona)* & 1.405 .426 & 1.273 .037 & $-9,42$ & 1.229 .496 & $-3,42$ \\
\hline Salamanca University (Old Building) & 164.136 & 154.202 & $-6,05$ & 118.767 & $-22,98$ \\
\hline
\end{tabular}




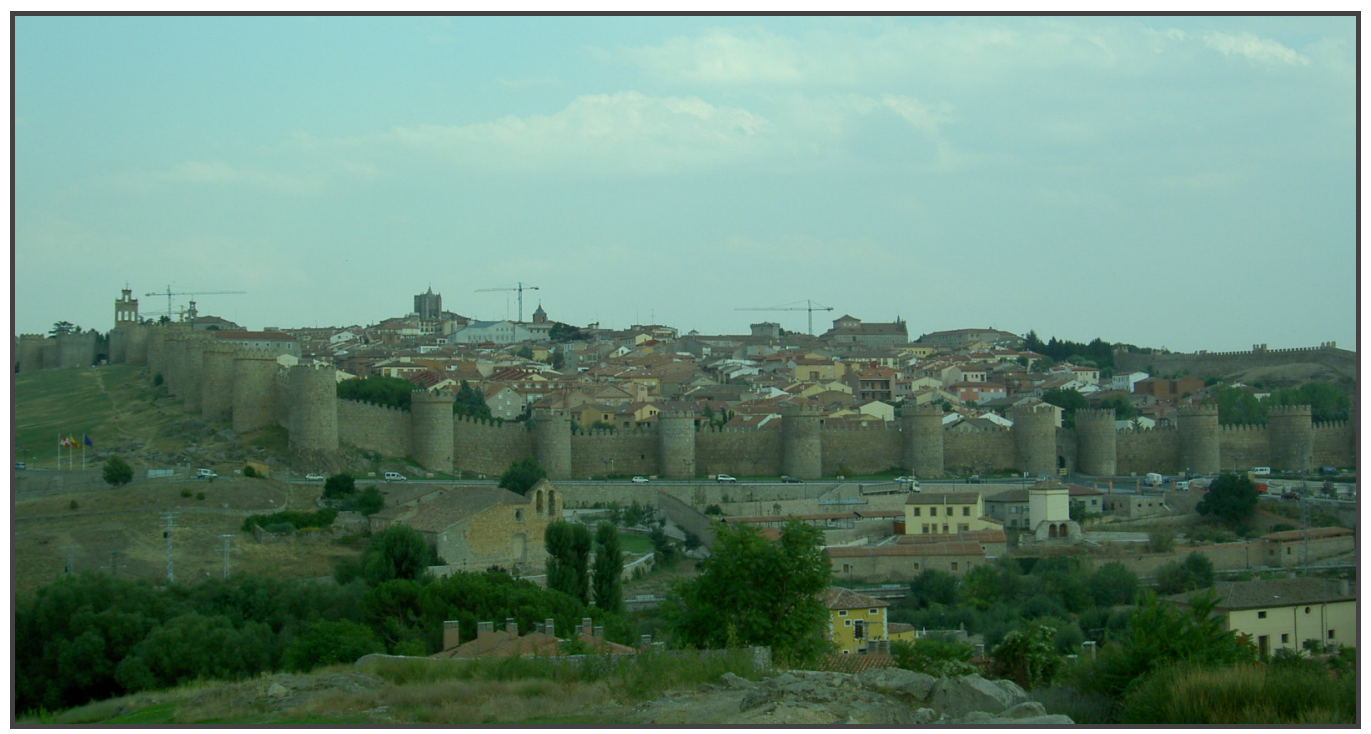

Fig. (3). Avila city wall.

Group visitors usually make up a larger percentage of the total in spring and autumn. In the case of the Avila walls (Fig. 3), it is worth noting that the high levels registered in springtime, with more than $50 \%$ of the groups that visited the city over the whole year $(53.48 \%)$, coinciding with the presence of a larger number of commercially organised tour groups, as against $23.52 \%$ in the summer months, and $16.02 \%$ in autumn. In St. Tomé, there are no large differences across the three seasons attracting the most tourists to the city. Autumn is the season with the highest number of group visitors, $29.64 \%$, with $26.81 \%$ coming in spring and $25.59 \%$ in summer, showing that this monument has a constant number of visits throughout the year. Winter, however, remains the least popular season for organising group tours, making up $6.98 \%$ of the visitors to the Walls of Avila and $17.96 \%$ to St. Tomé (Fig. 4).
In terms of trip type, we find a significant predominance of visitors travelling individually. Numbers of visitors in commercially organised group tours have been declining in recent years, while social tourists as a group are registering the highest growth rate. Furthermore, as far as the socioeconomic characteristics of the visitors go, it can be shown that the educational level of the visitors is higher than that of the average tourist.

Historic cities are consolidating their position as important destinations for short trips, with the percentage of visitors staying overnight generally standing at around $30 \%$, as the excursion sector of the domestic tourism market becomes stronger. The length of stay is rarely two nights. Another aspect, which characterises the tourist profile of historic cities is the focus of the tourist visit on a very limited core of the urban cultural network. This raises the possibility of a change in the model of tourist behaviour in such

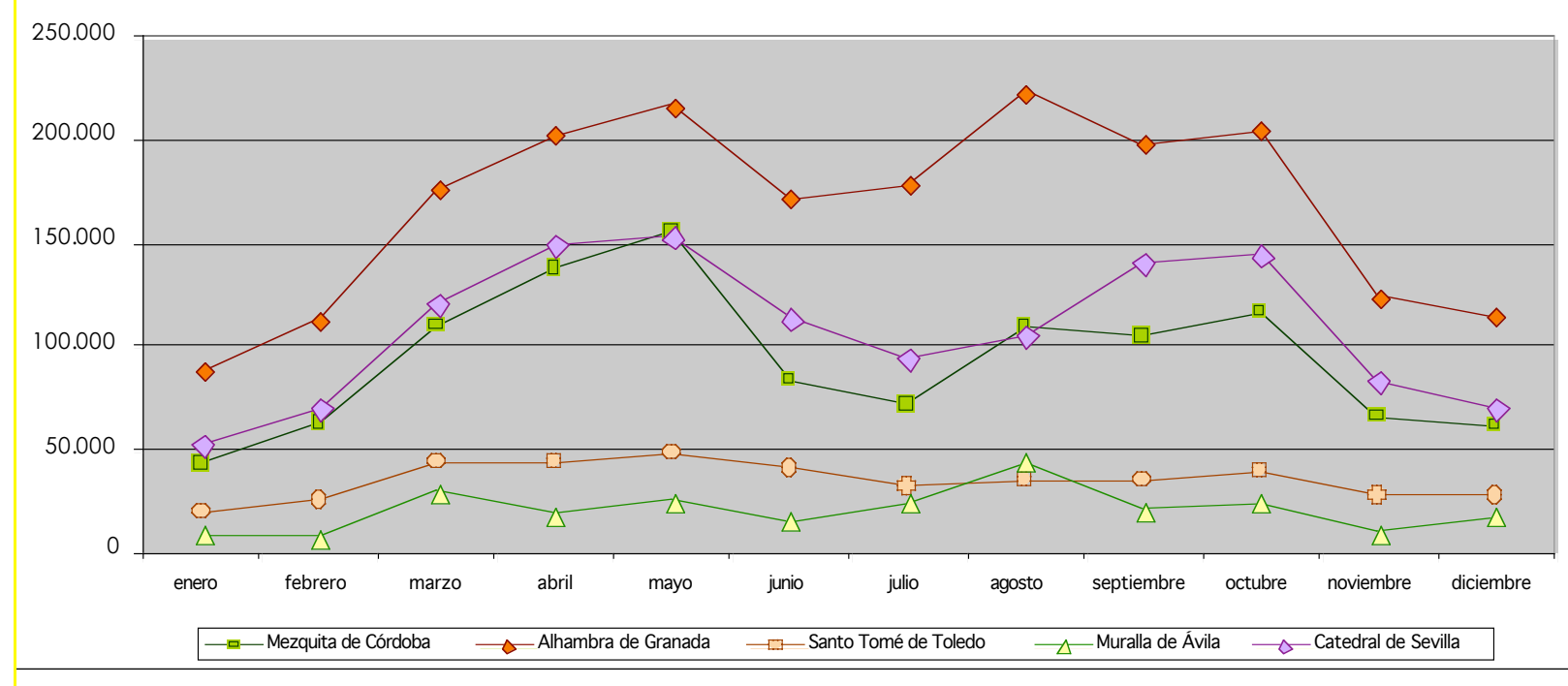

Fig. (4). Main monuments: monthly rate of visitors (2005). 
destinations, as visitors frequent museums and monuments less and less, spending their time instead by walking around, shopping, having meals or drinks in a leisure context, and as the number of repeat visits increases.

To sum up, historic cities are becoming very important destinations for urban/cultural tourism, although there are some important differences among them. This rise, linked to different types of tourist activity, has brought with it a remarkable increase in the number of competing destinations, forcing everyone to make an effort in order to maintain and expand their market share. City tourism is in a favourable position in general as regards to development. Indeed, weekend trips and short holidays have strengthened this type of tourism in cities such as Gerona, Seville, Barcelona or Santiago de Compostela.

\section{HERITAGE RECOVERY AND THE GROWING CONSOLIDATION OF TOURISM PLANNING}

Since the mid 1980s, considerable efforts have been made in Spain with regard to the recovery of heritage elements and the adaptation of cultural resources and heritage destinations as tourism products. Work has been done in several dimensions: urban planning (general and specific), heritage (declaration of sites of cultural interest, and the conservation and recovery of historic buildings and monuments), and tourism planning. The process has its ups and downs, but the situation of our historic cities has improved significantly [7]. To make this possible, the consortia of cities such as Santiago, Toledo, and Cuenca, as well as the governing boards, such as the Board of the Alhambra and Generalife [8], have played an outstanding role. The historic cities that have made an important effort in the recovery and value enhancement of their cultural heritage (Santiago, Gerona, Salamanca, Oviedo, Cuenca, Barcelona, Avila, Baeza, Tarragona, etc.) have been rewarded with significant improvements in their positions in the national and international tourist rankings.

Spain is a country in which tourism contributes around $12 \%$ of gross domestic product and it boasts a powerful and diverse cultural heritage with around 1,000 historic sites. Yet not a great deal of attention had previously been paid to the relationship between urban planning and tourism. Recent initiatives set up by the central government, autonomous communities, and some city councils (plans for tourism revitalisation and excellence, plan to boost cultural and language tourism, or the World Heritage Cities Product Club) show that a change has taken place, one which provides greater opportunities for urban, cultural and tourism strategies to meet. However, there are difficulties in improving coordination between institutions, empowering citizen participation, strengthening public/private collaboration and reorienting the promotion and development of tourism around new sustainability criteria [9]. In the case of heritage destinations, the main goal must be directed towards shaping a tourist strategy embedded within overall policy and capable of making the preservation of the cultural heritage compatible with its commercialisation, while at the same time reducing or minimising the risks of degradation of heritage sites, tourism, and the environment. This integrated perception of tourism in terms of the destination does not preclude the addition of a whole series of specific goals for the tourist sector: reinforcement and redefinition of the brand of the destination; diversification of the product palette; improvement of the relationship tourists/day trippers, increasing the length of stays, the length of the tourist season, and tourist spending; greater integration of tourism in the economy, in urban areas, in the daily life of the local community, etc, as described in Toledo XXI: Estrategia Turística para una Ciudad Patrimonio de la Humanidad [10].

At the beginning of the 1990s, the initial changes in the tourism policy models of historic cities start to appear, and tourism strategies going beyond mere promotion were designed [11] (Troitiño, 1998). Tourism became an important issue on the political agenda, and urban strategies which see tourism as an important factor for development and recovery began to be adopted. The changes in general tourism policy affected the intervention models at the destination, with the Futures I Plan (1992-1996) for example focusing on diversification, qualification, and the reinforcement of state intervention in tourism.

The launch of the plans for the revitalisation of tourism, which were instruments arising from multilevel agreements between central government, autonomic communities, and local councils, have made it possible for tourism, culture, and the economy to interact in urban strategies, even though operational difficulties have undoubtedly existed. Since the pioneering initiatives in the early $90 \mathrm{~s}$, the number of historic cities promoting plans for the revitalisation of and excellence in tourism has increased significantly [12].

The formulation and implementation of these plans has meant a change in the models used in tourism policy. In particular, with reference to historic cities, the following aspects stand out: the emphasis given to planning at the destination, the adoption of a strategic planning philosophy regarding tourist development, the acknowledgement of the central role played by the local administration, the existence of specific budgets, the creation of specific organs for the management of the plans and the search for a model of public-private cooperation with a view to achieving improvements for tourism in an integrated manner [13]. At a more general level, four important courses of action or procedures can be identified: the improvement of the tourism-heritage product; the adaptation of local hospitality resources; publicising the destination; and diversifying activities. The success of the model of tourism planning for the destination has also meant a change in the tourism culture of local entrepreneurs, something that has not always been easy to achieve. Some of these policies, such as the Salamanca Tourism Excellence Plan (2001-2003) [14], were innovative in their interpretation of tourism and their approach towards planning for it (Table 2).

The cultural heritage of historic cities, is still partially limited in terms of its development as a product for tourism. Only a small fraction of historic buildings are suitable and adapted for opening to the public. For example, of the 62 buildings in Granada classified as Sites of Cultural Interest only 17 are wholly or partly adapted to the public [15]; in 
Table 2. Salamanca Tourism Excellence Plan: Projects by Line of Action

\begin{tabular}{|l|}
\hline A. Activities Relating to the Product \\
A.1. A new presentation of heritage building exteriors \\
* Project: Lighting \\
* Project: Presenting the city through shows \\
* Project: Theatrical exhibition of the city \\
* Project: Signposting \\
* Project: Preparation of surroundings \\
A.2. Promotion and improvement of heritage interiors \\
* Project: value enhancement of interiors \\
A.3. Welcoming the visitor \\
* Project: Budgets and infrastructure \\
A.4. Complementary activities \\
* Project: Coordination of complementary activities \\
\hline B. Promotion, Publicity and Brand Image \\
* Project: Global publicity campaign \\
\hline C. Commercialisation \\
* Project: Commercialisation of an attractive product palette \\
\hline D. Development of Tourism Management Structures \\
D.1. Complementary activities with local agents \\
* Project: Improvement of product palette quality \\
\hline E. Management of the Tourism Excellence Plan \\
* Project: Management \\
Source: [14].
\end{tabular}

Toledo, out of 99 SCIs 10 are principally used for tourism, 7 partly and 82 occasionally [16] (Fig. 5); in the Autonomous Community of Madrid, according to the index of SCIs, only 13 out of 402 SCI classified buildings are used principally for tourism, with 63 at a secondary and 326 at an incidental level [17]. The creation of new products has frequently been based on the value enhancement of existing heritage resources, and within this philosophy we can find projects such as the enhancement and adaptation for tourism of the Avila city walls [18].

Over recent years, a great effort has been made in adapting cultural resources as products for tourism, in preparing heritage destinations, in expanding the range of museums, in strengthening the tourism dimension of cultural and tourist events (Salamanca 2002 (Fig. 6), Xacobeo 2004, the Barcelona Forum, the Gaudí and Dalí years, the Quijote and Columbus centenaries, etc.), and organising exhibitions with important tourism appeal (The Tree of Life in Segovia, The Spanish Portrait, The Avila Witnesses, Kyrios, etc.) There is a strong commitment to the diversification of the classic heritage product and the overall quality of the destination.

\section{EMERGING DESTINATIONS AND RELEVANT EXPERIENCES: THE CLUB OF WORLD HERITAGE CITIES}

Spain has 39 cultural sites included in the World Heritage list, and historic cities play a special role. In the context of UNESCO's Cultural and Natural Heritage Convention and the World Heritage Cities Organisation, the Spanish World
Heritage Cities Group (Avila, 1993) was founded (Fig. 7). The statutes of the group highlight, among other aims, that of "planning a tourism and publicity policy adequate to the needs of the city members of the group," and in 1994 the first agreement was signed with the Ministry of Trade and Tourism.

The Spanish World Heritage Cities Group is currently made up of 13 cities: Alcala de Henares, Avila, Caceres, Cordoba, Cuenca, Ibiza (Fig. 8), Merida, Santiago de Compostela, San Cristobal de la Laguna, Salamanca, Segovia, Tarragona, and Toledo (Fig. 9). In terms of tourism, it focuses on the areas of joint promotion, group presentations, agreements with other administrations, joint leaflets to build brand image, web presence, etc. An "agreement on a cooperation framework for the development and tourism promotion of the Spanish World Heritage Cities Group" was signed in 2003, with a renewable 3 year lifespan. The key aims of this agreement are the improvement of public services provided by the city councils and the strengthening of tourism as much at the national as international level for the destinations, the expansion of the Model for Integrated Quality Management of Tourist Destinations, the implementation of a Quality System for Tourist Information Offices, annual action plans, and international advertising campaigns, commercialisation plans, range of cultural attractions.

The cities comprising the Group have made an admirable effort over recent years in the recovery and value enhancement, both in cultural and tourism terms, of their rich and diverse heritage, as well as in adapting the cities and their heritage buildings for opening to the public and in tourism management models, even when results have been uneven [19]. All cities, with the exception of San Cristobal de la Laguna, have run or are running Plans of Excellence or Tourism Revitalisation. In 2004, the Spanish World Heritage Cities Product Club was formed with a clear commitment to a professionalised and integrated management of tourist destinations, to quality and to national and international promotion.

The commitment to heritage destinations appears firm and the results have been quite encouraging. The number of visitors to the principal sites and museums remains at significant levels, the stock of hotels and restaurants has been substantially increased (Tables $\mathbf{3}$ and 4); heritage destinations have reinforced their tourism position, contributing not only to diversifying the product range but also to distinguishing the visits and making them compatible with other destinations.

\section{ALLIANCES AND TENSIONS BETWEEN DIFFERENT POLICIES AND STRATEGIES}

Value enhancement and the adaptation of cultural heritage sites as a tourism resource is a complex and lengthy process, which requires action on the urban heritage and tourism fronts. Thus, in order to go beyond the provision of core tourism infrastructure and facilities and properly apply innovative and sustainable tourism strategies, a commitment must be made to transverse management tools with a strong capacity to coordinate public administrations and to act as an interface between these and the private sector. As an 


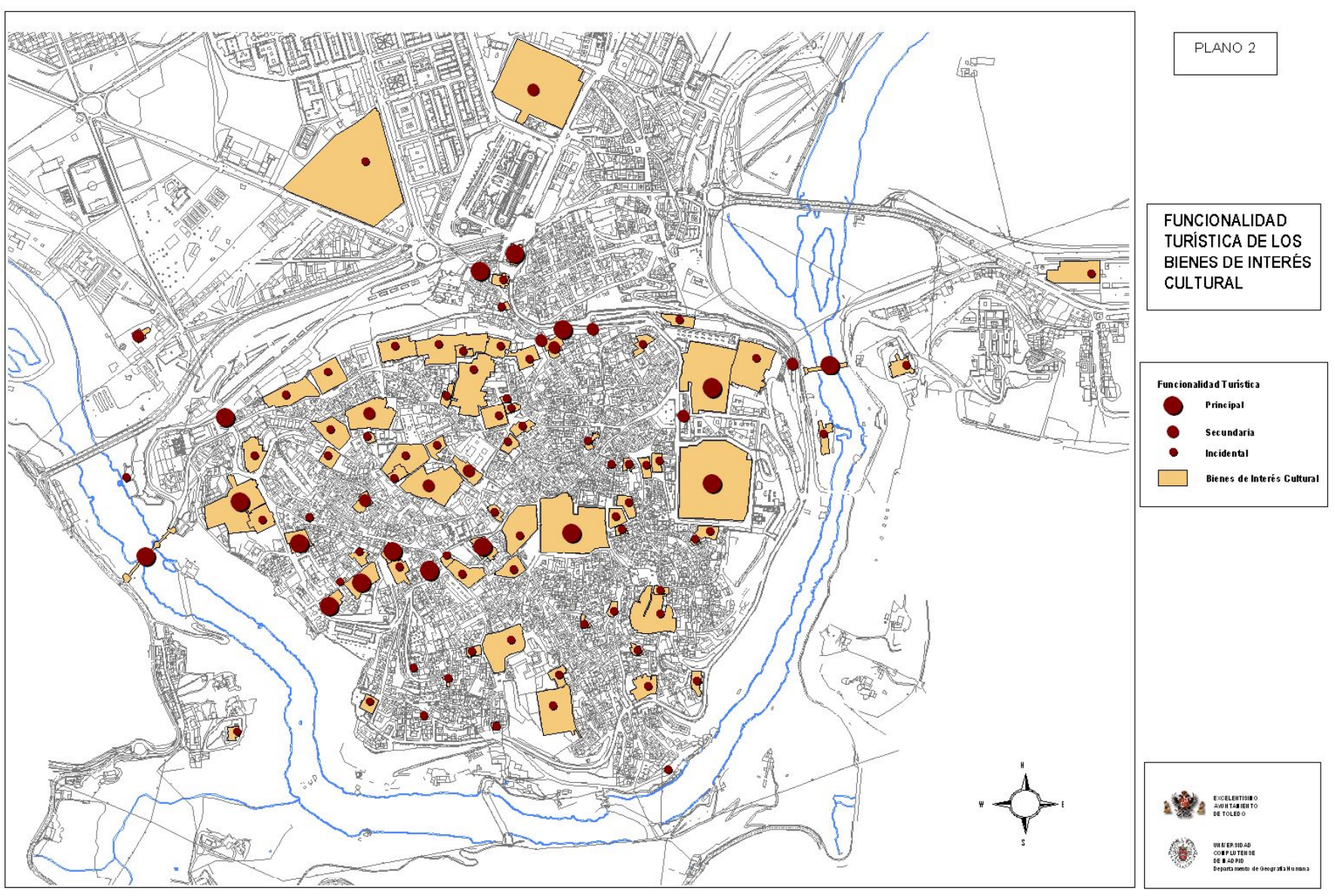

Fig. (5). Tourist functionality of BIC of Toledo 2005.

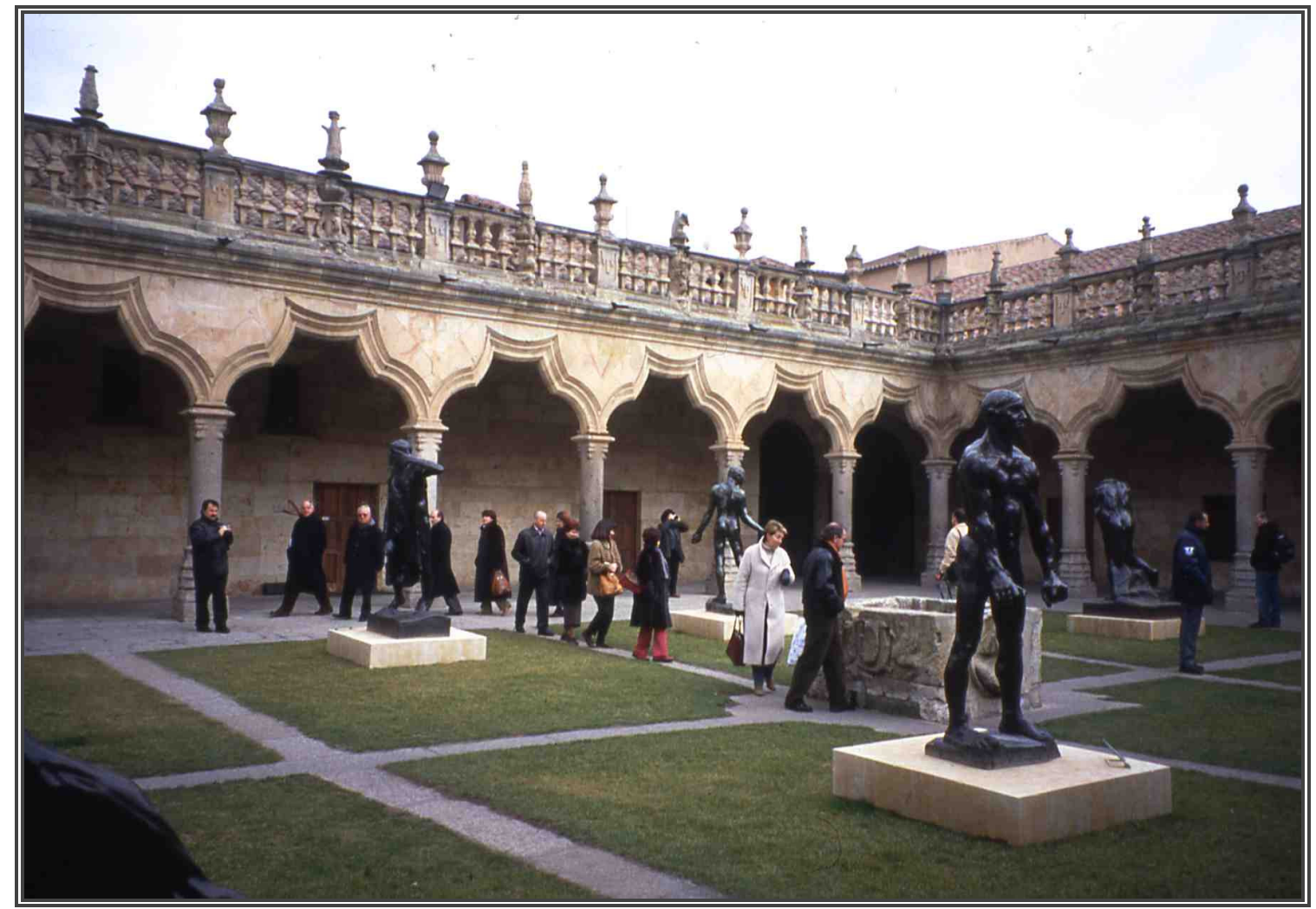

Fig. (6). Salamanca. Smaller Schools. Exhibition of Rodin 2002. 


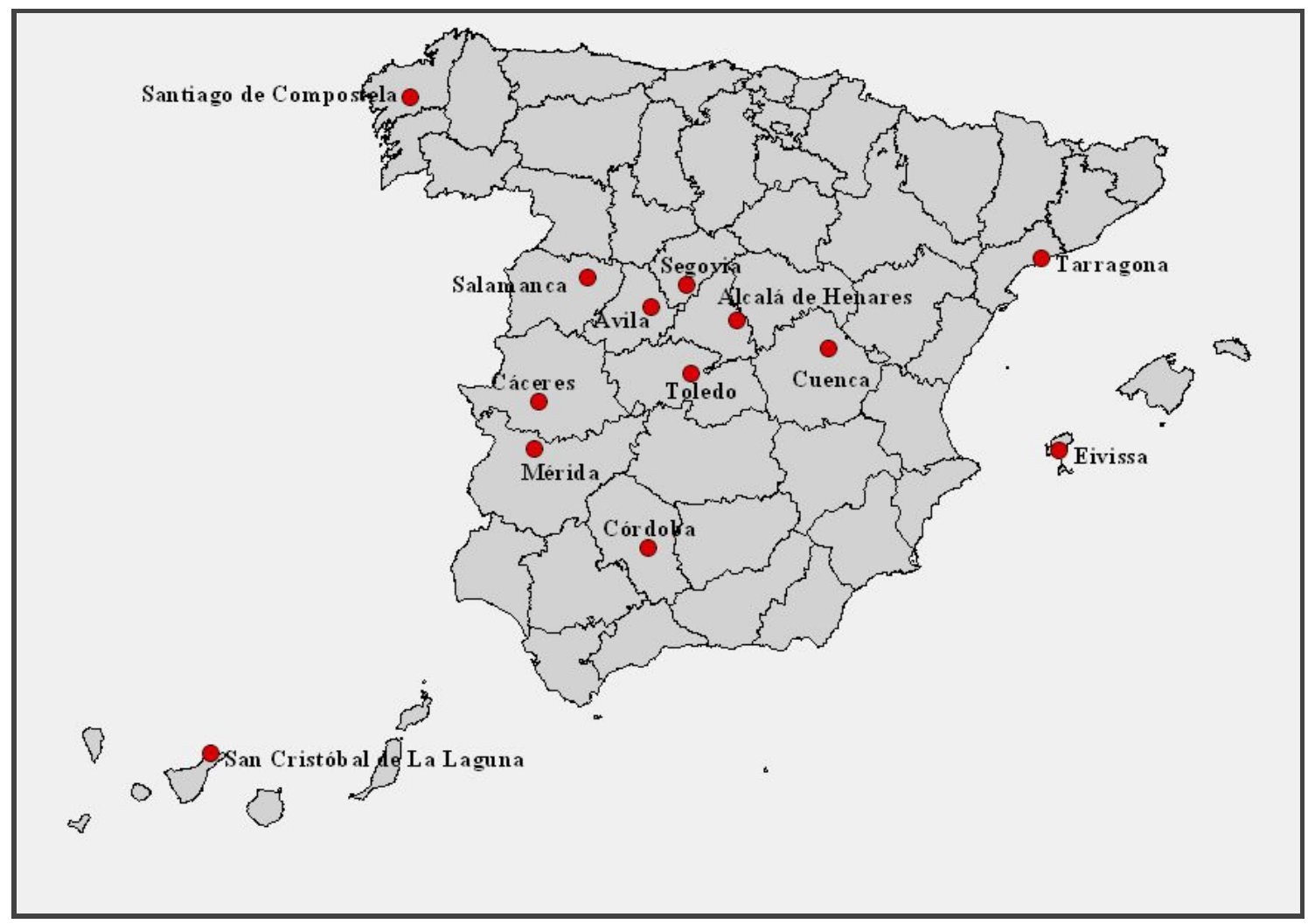

Fig. (7). Spanish group of world heritage cities.

example, we present below a synthesis of the process by which the historic city of Cuenca is enhancing the value of its cultural heritage and is consolidating as an important tourist destination.

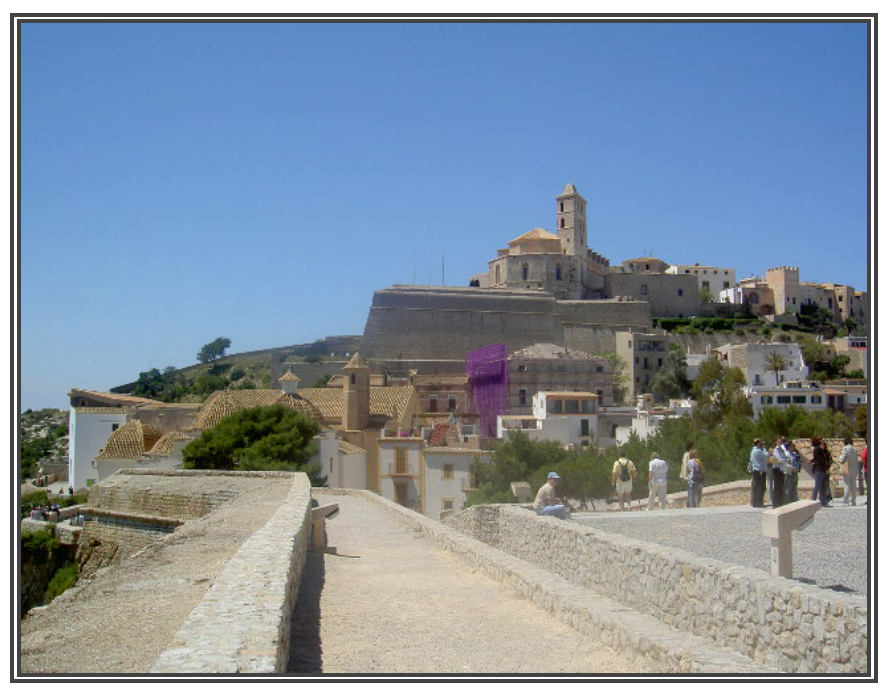

Fig (8). Dalt Vila (Ibiza).

Early in the final third of the $20^{\text {th }}$ century, the historic city of Cuenca was a heterogeneous area at functional and social levels which needed an integrated recovery strategy [20]. At the end of the 70s, a review was carried out of the General Urban Plan, which included a Special Plan for the Protection and Improvement of the Historic City, and in 1980, work was began on the Pilot Programme for Rehabilitating the San Martin area. Over the last two decades, during which time investment in the area has surpassed the 100 million Euro mark, the historic city has undergone a thorough recovery of its heritage buildings and monuments.

The aim of the Cuenca en Plena Luz programme, sponsored by the Castilla La Mancha government, has since 1989 been the complete rehabilitation of the upper city. The offer of rehabilitation grants has been widely taken up, triggering a dynamic improvement process in residential areas. The results of the Cuenca a Plena Luz programme, which have been quite positive in general, show that even with limited financial aid, by coordinating the activities of different sectors and with a serious management effort, a process can be launched which has benefited around $40 \%$ of households in the historic centre in some measure.

In recent years, the upper city has undergone serious reinforcement in terms of culture and tourism. Developments in socio-cultural and educational areas and in hotel accommodation have become fundamental to physical recovery and functional revitalisation. Despite some difficulties, multi-functionality has been maintained. However, tourism development is not without its problems and exerts pressures on the residential function, mobility and the need for new infrastructure, etc.

The Integrated Project of Urban Improvement Directed at Tourism 1994-1999, as part of the programme of European Regional Development Funding (ERDF), came about as one of the instruments to develop and finance the Special Plan of Protection, Organisation and Improvement of the Historic Centre and the Gorges. This project, with an investment of almost 20 million Euros, had the following main aims: improving pedestrian access and mobility, constructing 
parking spaces for residents and visitors, reducing the amount of private traffic and increasing public transport, eliminating physical barriers, recovering degraded urban areas, building a hospitality centre for visitors, renovating the infrastructure and paving inside the historic city and improving public spaces. Apart from the difficulties inherent in working in a historic city, the implementation of the Integrated Urban Improvement Plan has shown the irrational effects of political battles, the problems of coordination between cultural heritage and urban policies, weaknesses in infrastructure and local government management, and the difficulties in organising a project which needs to be collectively debated, accepted and shared in order to have a future.

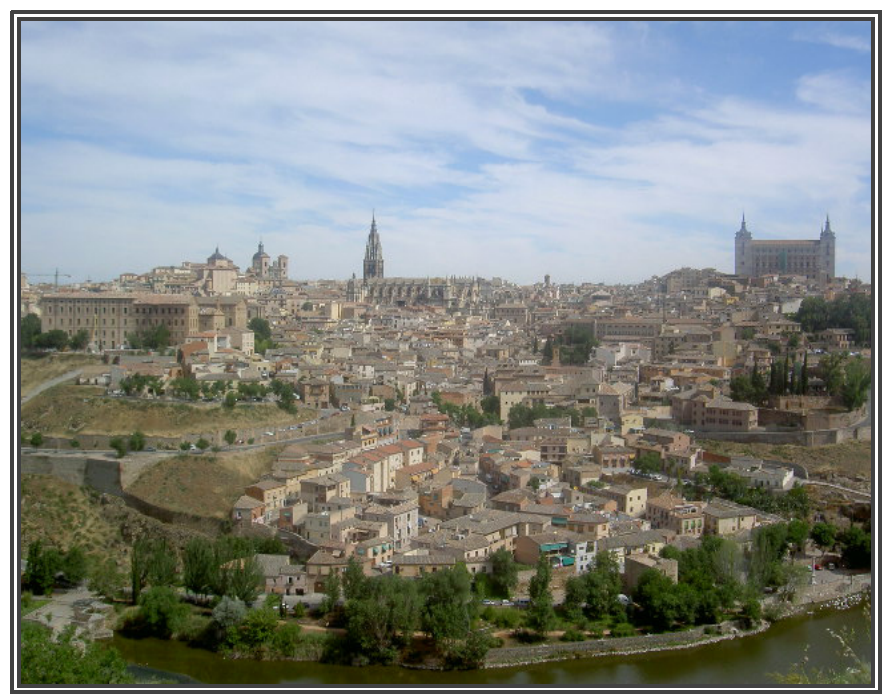

Fig. (9). Panoramic view of the historical centre of Toledo.

The Tourism Revitalisation Plan, approved in 1998, with an investment of 2.7 million Euros, has attempted to contribute to the preparation of the city, especially its historic centre, as an attractive and quality destination. Launched in 1999 in an atmosphere of cooperation between local governments and an initially low level involvement in the Provincial Hotel and Tourism Association, the Tourism Revitalisation Plan has managed to partially overcome the barriers of tourism planning by sector, and its activities focus around three main programmes: improving the product; promotion, publicity, and commercialisation; management.

The addition of Cuenca to the Cultural World Heritage list (1996) has reinforced a strategy of urban recovery in which urban planning, heritage, and tourism have to get along together. Thus, the setting up in 2004 of the Royal Board of the City of Cuenca (Fig. 10) and the launch of the City of Cuenca Consortium in 2005 need to contribute the resources and the management model, which will permit the realisation of urban recovery programmes with a balanced integration of the tourism function. Along these lines, the investment plan of the Royal Board (2006-2009) has established an investment of 38.7 million euros and around 50 concrete actions aimed at preserving and restoring the city's cultural heritage, as well as putting it on the map as a quality heritage destination.

The consolidation of Cuenca as an important centre for interior tourism and the transformation of the historic city into a centre for leisure for visitors and local people alike has generated an important increase in the number of visitors (from around 400,000 in the early 1990s to currently around one million), in the number of hotel beds (from 858 in 1991 to 1893 in 2006), and the number of restaurants (103 establishments offering 7331 seats) [21]. This expansion is beginning to generate some friction with the local population, especially at weekends, through traffic and parking problems.

As a final reflection, one has to take into account the physical, symbolic and functional identity of each historic city, and should refrain from asking for more in terms of

Table 3. Guests and Overnight Stays in WHCG Hotels 2004-2005

\begin{tabular}{|c|c|c|c|c|c|c|c|}
\hline & \multicolumn{3}{|c|}{ Tourists 2004} & \multicolumn{3}{|c|}{ Tourists 2005} & \multirow{2}{*}{ Variation 04-05 \% } \\
\hline & Total & Spanish & Foreign & Total & Spanish & Foreign & \\
\hline Ávila & 222.139 & 194.801 & 27.338 & 225.626 & 196.159 & 29.467 & 1,57 \\
\hline Cáceres & 206.667 & 182.386 & 24.281 & 224.707 & 203.623 & 21.084 & 8,73 \\
\hline Córdoba & 697.833 & 450.472 & 247.361 & 731.022 & 478.923 & 252.099 & 4,76 \\
\hline Cuenca & 203.019 & 181.617 & 21.402 & 209.196 & 190.000 & 19.196 & 3,04 \\
\hline Eivissa & 269.215 & 109.204 & 160.011 & 262.474 & 126.113 & 136.361 & $-2,50$ \\
\hline Mérida & 168.516 & 143.555 & 24.961 & 170.767 & 147.814 & 22.953 & 1,34 \\
\hline Salamanca & 529.816 & 388.072 & 141.744 & 554.008 & 416.179 & 137.829 & 4,57 \\
\hline $\begin{array}{l}\text { Santiago de } \\
\text { Compostela }\end{array}$ & 617.201 & 443.344 & 173.857 & 534.716 & 354.455 & 180.261 & $-13,36$ \\
\hline Segovia & 168.501 & 128.605 & 39.896 & 160.538 & 128.969 & 31.569 & $-4,73$ \\
\hline Tarragona & 181.217 & 133.915 & 47.302 & 195.989 & 144.713 & 51.276 & 8,15 \\
\hline Toledo & 412.495 & 285.652 & 126.843 & 434.616 & 314.932 & 119.684 & 5,36 \\
\hline Total & 3.676 .619 & 2.641 .623 & 1.034 .996 & 3.703 .659 & 2.701 .880 & 1.001 .779 & 0,74 \\
\hline
\end{tabular}


Table 4. Heritage City Hotel Beds 2004-2005

\begin{tabular}{|l|c|c|c|}
\hline & Estimated Number of Beds. August 2004 & Estimated Number of Beds. August 2005 & Variation 04-05 in \% \\
\hline \hline Ávila & 1.868 & 2.191 & 17,29 \\
\hline Mérida & 1.492 & 1.480 & $-0,80$ \\
\hline Eivissa & 9.200 & 8.867 & $-3,62$ \\
\hline Cáceres & 1.966 & 2.266 & 15,26 \\
\hline Córdoba & 5.706 & 5.725 & 0,33 \\
\hline Santiago de Compostela & 6.822 & 6.903 & 1,19 \\
\hline Cuenca & 1.856 & 1.911 & 2,96 \\
\hline Salamanca & 5.079 & 4.925 & $-3,03$ \\
\hline Segovia & 1.357 & 1.258 & $-7,30$ \\
\hline Tarragona & 2.819 & 2.777 & $-1,49$ \\
\hline Toledo & 3.381 & 3.801 & 12,42 \\
\hline Soure: Hotel Ocup & & \\
\hline
\end{tabular}

Source: Hotel Occupancy Survey, INE (National Statistics Institute). Beds available in August 2004-2005.

tourism than each can or should give. What is needed is the implementation of qualitative strategies, arrived at through a consensus among social agents and in accord with each city's capacity for receiving visitors. Asking for more means treading the risky path of unsustainability, both in terms of culture and tourism. In order to avoid this, it is necessary to seek out innovative management and take on board transversal instruments such as consortia, boards, foundations, etc., which, depending on the features of each destination, enable the formulation of integrated strategies and the bringing together of public and private spheres in the formulation of projects and the launch of specific activities.

Tourism is a phenomenon of interdependencies and its relationship with historic cities is multifaceted, with both positive and negative aspects. In any case, it plays an important role in the current processes of change, and this raises an important challenge: to overcome the merely promotional phase of tourism management and to succeed in integrating tourism in the heritage destinations, exploiting it as an important instrument in functional revitalisation and renovation.

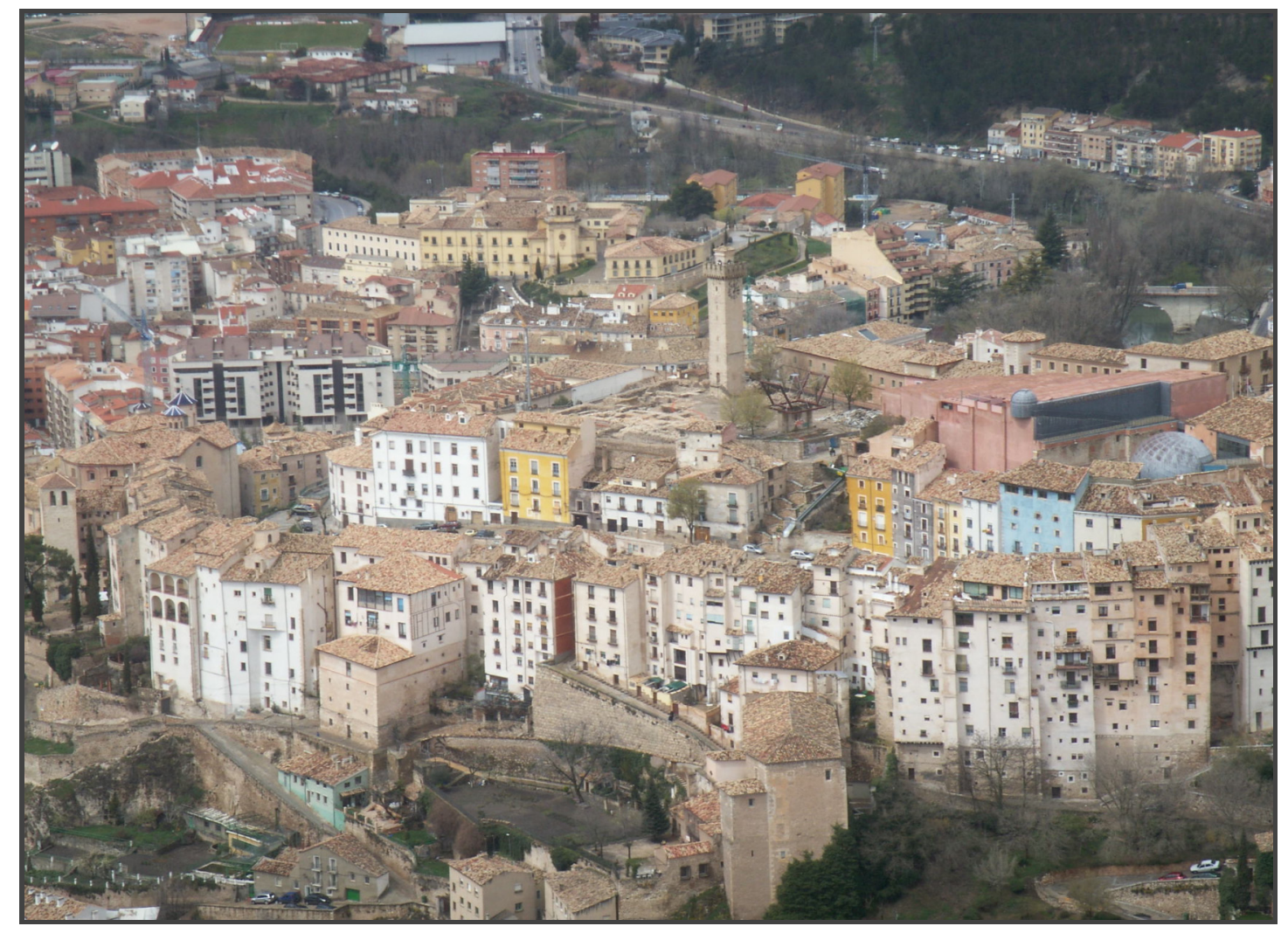

Fig. (10). Historical city of Cuenca. 


\section{REFERENCES}

[1] Brandis D, del Rio I. La dialéctica turismo y medio ambiente de las ciudades históricas: una propuesta interpretativa. Ería 1998; 47: 229-40.

[2] Troitiño VMA, Troitiño TL. Turisme cultural: un segment emergent difícil de cuantificar. Nexus 35. Noves polítiques per al turisme cultural: reptes, ruptures, respostes, 2006. Pp. 44-65.

[3] Turespaña. Estudios de Productos Turísticos. Turismo Cultural. Madrid: Ministerio de Economía 2001.

[4] Movimientos turísticos en fronteras (Frontur, 2006). Madrid: Tourspain 2006. Avaliable from: http://www.iet.tourspain.es/infor mes/documentacion/frontur/MovimientosTuristicosEnFronteras200 6.pdf

[5] Observatorio de Turismo Cultural de la U.C.M. Madrid 2003-2005.

[6] Troitiño MA, Calle M De La, García M. Las ciudades históricas españolas como destinos turísticos. In: AAVV. La Actividad Turística Española en 1999. Madrid: AECIT 2000; pp. 545-56.

[7] Troitiño VMA. (2003): La protección, recuperación y revitalización funcional de los centros históricos. Mediterráneo Económico 2003; 3: 131-60.

[8] Chamorro V. La Alhambra. El lugar y el visitante. Junta de Andalucía. Córdoba: Consejería de Cultura 2006.

[9] Troitiño VMA. Retos y oportunidades en la gestión del turismo cultural y de ciudad. In: Gómez MA, Mondéjar MA, Sevilla Cl, Eds. Gestión del Turismo Cultural y de Ciudad. Cuenca: Universidad de Castilla-La Mancha: Cuenca 2005; pp. 15-27.

[10] Troitiño MA, Prast F. Toledo 21. Una estrategia turística para una Ciudad Patrimonio de la Humanidad. Toledo: Cámara de Comercio e Industria de Toledo 1998.

[11] Troitiño VMA. Turismo y ciudades históricas: la experiencia española. In: Marchena M, Ed. Turismo urbano y patrimonio cultural. Una perspectiva europea. Sevilla: Diputación de Sevilla 1998; pp. 89-105.

[12] Brunet P, Almeida F, Coll M, Monteserin O. Los Planes de Excelencia y Dinamización Turística (PEDT), un Instrumento de Cooperación a favor del Desarrollo Turístico. Boletín de la Asociación de Geógrafos Españoles 2005; 39: 201-26.
[13] Calle VM De La. La Ciudad Histórica como destino Turístico. Barcelona: Ariel Turismo 2002.

[14] Salamanca Tourism Excellence Plan. Strategic Plan. Technical team: I.C.N.-ARTEA, S.L. 2001

[15] Troitiño MA, Brandis D, Del Río I, Gutiérrez J, De la Calle M, García M. Estudio Previo de revisión del Plan especial de la alhambra y alijares. Documento previo de síntesis y diagnóstico. Granada: Patronato de la Alhambra y Generalife 1999.

[16] Troitiño TL. La oferta patrimonial y cultural de la ciudad de Toledo y su funcionalidad turística. In: VIII Forum Internacional sobre Las Ciencias, las Técnicas y el Arte Aplicadas al Marketing”. Madrid: Universidad Complutense de Madrid. Facultad de Ciencias Económicas y Empresariales 2005; pp. 415-34.

[17] Troitiño MA, García M, De La Calle M. Turismo y ciudad histórica: metodología de análisis a escala local. In: Turismo y cambio territorial eclosión, aceleración, desbordamiento?. IX Coloquio de Geografía del Turismo, Ocio y recreación. Zaragoza: Prensas Universitarias de Zaragoza 2006; pp. 665-96.

[18] García HM. Ávila: planificación y gestión turística local en una ciudad patrimonio de la humanidad. In: Joseph Font Sentias, Coord: Casos de Turismo Cultural. De la planificación estratégica a la gestión del producto. Barcelona: Ariel 2004; pp. 413-41.

[19] García M, Calle M. Nuevas estrategias para la renovación del producto turístico urbano: El caso de las ciudades Patrimonio de la Humanidad. In: VIII Forum Internacional sobre Las Ciencias, las Técnicas y el Arte Aplicadas al Marketing. Madrid: Universidad Complutense de Madrid. Facultad de Ciencias Económicas y Empresariales 2005; pp. 386-414.

[20] Troitiño VMA. Políticas urbanas y dinámicas funcionales en el centro histórico de Cuenca. In: Campesino Fernández A, Coord. Comercio, turismo y cambios funcionales en las ciudades españolas Patrimonio de la Humanidad. Cáceres: Cámara Oficial de Comercio e Industria de Cáceres 1999; pp. 81-109.

[21] Troitiño TL. Oferta patrimonial e infraestructura turística en la ciudad de Cuenca. In: Troitiño MÁ, García, JS, García M. Eds. Destinos turísticos: viejos problemas, ¿nuevas soluciones? X Coloquio de Geografía del Turismo, Ocio y Recreación. AGE. Cuenca: Universidad Castilla La Mancha. 2008; pp. 323-36.

(C) Vinuesa and Torralba; Licensee Bentham Open.

This is an open access article licensed under the terms of the Creative Commons Attribution Non-Commercial License (http://creativecommons.org/licenses/by$\mathrm{nc} / 3.0 /$ ) which permits unrestricted, non-commercial use, distribution and reproduction in any medium, provided the work is properly cited. 